\title{
Pathogen threat spurs research initiatives
}

Rex Dalton, San Diego

Interest in the risks posed by highly contagious fatal pathogens is prompting several US universities to set up special laboratories and research programmes to study emerging microorganisms and bioterrorism.

"There is a realization that emerging viruses are not going to go away," says virologist Michael Buchmeier of the Scripps Research Institute in La Jolla, California. The nation "has been complacent", he says. Now the pathogens "are staring us in the face".

Deadly microorganisms targeted for study include the Ebola, Marburg and Lassa fever viruses from Africa. There is also interest in other arenaviruses previously found in Latin America but now identified in California. West Nile virus and dengue fever viruses are also emerging as potential threats to public health. And there is growing official concern about bioterrorism involving agents such as anthrax and Bolivia's Machupo virus (see Nature 411,232-235; 2001).

Many researchers say the study of these pathogens has been hampered by a lack of academic facilities, as they must be housed in labs with a tough safety designation known as Biosafety Level 4 (BSL-4).

Research is at present concentrated at the Centers for Disease Control and Prevention (CDC) in Atlanta, Georgia, and at a US Army base at Fort Detrick in Maryland. The National Institutes of Health (NIH) also has a small BSL-4 lab for antibioticresistant tuberculosis research in Bethesda, Maryland. And last year the Southwest Foundation for Biomedical Research in San Antonio, Texas, expanded its BSL-4 facilities. These had been restricted to a containment box with access through gloved arms, and now have a walk-in laboratory where scientists wear protective suits.

These facilities were previously the only BSL-4 laboratories in the United States. But in August the University of Texas Medical Branch (UTMB) at Galveston will start building a \$10.5-million facility that should be finished by late next year. Last December, the UTMB recruited C. J. Peters, the CDC's head of the Special Pathogens Branch, to run the BSL-4 lab. And last month, the NIH certified the university's safety plans.

The California Department of Health Services and the University of California, Davis, are meeting regularly to plan another facility, which they hope to build for an estimated \$50 million. Current discussions envisage that the state will fund construction of the BSL-4 laboratory on the Davis campus, with the university operating the lab.

At Texas Tech University in Lubbock, meanwhile, officials are planning a $\$ 98.5-$ million research facility that would include a BSL-4 lab at the decommissioned Reese Air Force base outside Lubbock. Last month, Texas Tech's board of regents voted to seek $\$ 4$ million for design plans for the facility, which would focus on bioterrorism.

And the University of New Mexico in Albuquerque is exploring funding possibilities for a BSL-4 lab to extend its research on hantaviruses, says biologist Terry Yates, the university's new vice-president for research.

Both Texas Tech and New Mexico may look to Congress for funding for their facilities, officials say. In 1995, Texas A and M at College Station failed to secure funds from Congress for a BSL-4 lab. Officials there say they remain interested, but are not actively planning a facility. But attempts by other universities to get congressional funding may reinvigorate Texas A and M's plans.

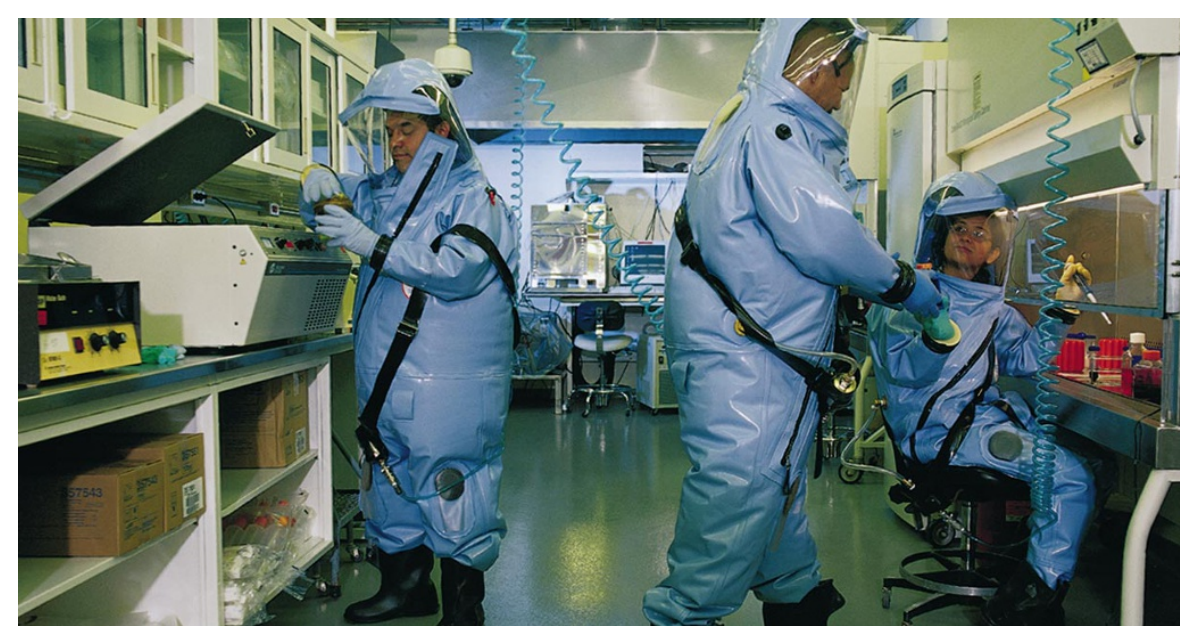

Germ warfare: several labs dedicated to the study of emerging virulent pathogens are planned in the US.

\section{UK election sees revamp for farming and environment}

\section{David Adam, London}

Discredited by the bovine spongiform encephalopathy (BSE) epidemic and still reeling from the effects of foot-and-mouth disease, Britain's Ministry of Agriculture, Fisheries and Food (MAFF) has finally been put out of its misery.

In a government reorganization that quickly followed the Labour party's overwhelming re-election on 7 June, Prime Minister Tony Blair announced that MAFF will be replaced by a new department that will seek an integrated approach to managing agriculture and the environment.

The new Department for Environment, Food and Rural Affairs (DEFRA) will now coordinate and fund research previously supported by MAFF, as well as work concerned with the environment, rural development, countryside, wildlife and sustainable development. These additional functions are inherited from the former Department of the Environment, Transport and the Regions, which has been broken up. DEFRA will be headed by Margaret Beckett, a former head of the Department of Trade and Industry (DTI).

The rest of Britain's apparatus for managing research and science policy will remain largely intact, after an election campaign in which science-related issues played little visible role. Lord Sainsbury, who as science minister is responsible for day-today science policy and oversees the research councils that provide the main support for academic research in Britain, was expected to stay in the same job. Patricia Hewitt, formerly the minister responsible for electronic commerce, will replace Stephen Byers as head of the DTI, giving her Cabinet-level responsibility for science and technology.

David Shannon, chief scientist with the former MAFF, describes the plans for DEFRA as "ambitious". He says its creation was necessary to resolve conflicts in the way agricultural and environmental issues were handled.

But some point out that this joint responsibility could cause the new body problems, and question whether the changes have been adequately thought out."I think there is a serious danger that this is just window-dressing," says a senior official at one scientific society. 